\title{
Review on the Book: Advances in Water Quality Control
}

\section{Thangarasu Pandiyan}

Faculty of Chemistry, National Autonomous University of Mexico (UNAM), Mexico.

Email: pandiyan@unam.mx

Received March $1^{\text {st }}$, 2012; revised March 31 ${ }^{\text {st }}$, 2012; accepted April $13^{\text {th }}, 2012$

Advances in

\section{Water Quality Control}

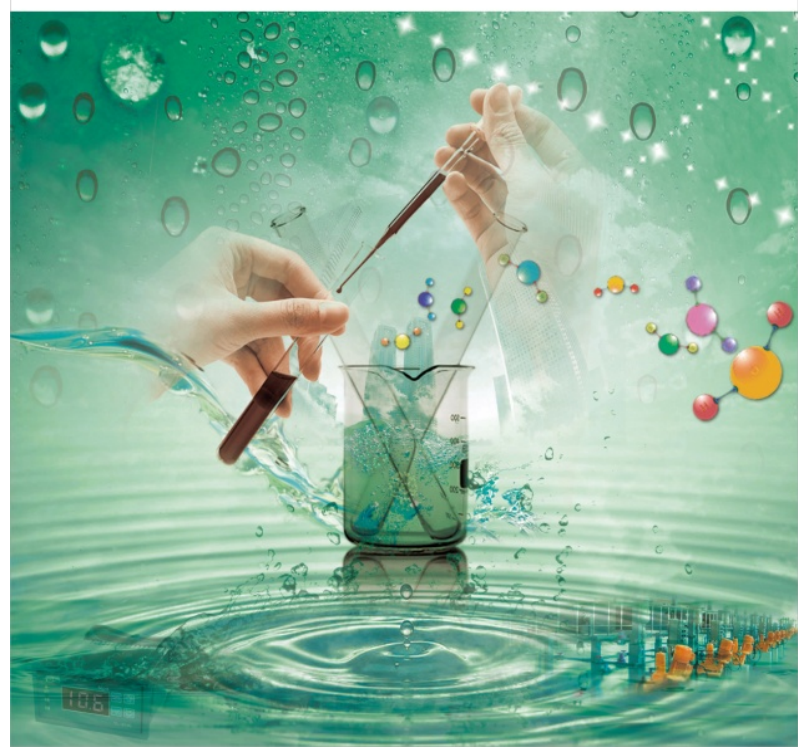

ISBN: 978-1-935068-08-2

316pp Pub.Date: October/2010

Price: $\$ 89$

Water pollution is a steadily worsening problem because of growth in the chemical, pharmaceutical, leather, textile, and mining industries. In addition, municipal wastewater further contributes to polluting pure water sources. Hence, adequate treatment is essential before it released to avoid pollution of pure water sources. Chapter 3 describes guidelines for wastewater treatment taking into account its physical, chemical and mechanical nature. The guidelines are also helpful in maintaining the operational treatment facilities; it is estimated that 10 to 20 percent of wastewater treatment facilities even in developed countries are not operating properly. Treatment methods are divided into conventional and Natural biological processes and the advantages and drawbacks of each are clearly explained. The influential parameters are identified for the primary (settling to remove solid wastes), secondary (bacteria in removing pollutants) and tertiary (involving advanced techniques such as Biological Nutrient Removal) water purification methods, particularly municipal wastewater treatments.

The biological treatment process via microorganisms is particularly suited for Lagoons, Ponds and wetlands because they avoid secondary by-products contaminants. Guidelines are given for the construction of artificial lakes and ponds to be used for wastewater treatment, and diagrams, designs, schemes, and mathematical models are provided. These can also be used for some difficult industrial wastewaters as well as for municipal water containing pharmaceuticals and personal care products. The author emphasized that wetland treatment is often the best choice for the pre-treatment of water and wastewater based on cost and the efficiency. This wastewater treatment chapter is very useful for environment researchers, and engineers, ecologist and the environmental education programs.

\section{To order: http://www.scirp.org/book/}

\section{bookorder@scirp.org}

